Check for updates

1 Earlsfield Foodbank in south west London

Cite this as: $B M J$ 2021;375:n2846 http://dx.doi.org/10.1136/bmj.n2846 Published: 18 November 2021

\title{
Our worst fears about the impact of Universal Credit cut are coming true
}

\section{A month after the cut to Universal Credit, Charlotte White reflects on increasing need for the independent food bank she runs in south-west London}

\section{Charlotte White manager}

Lara, a new guest, is completing our registration process. Lara has learning disabilities, so her support worker, Sam, is with her to help complete the necessary form. We go through the usual questions-some basic details, plus a conversation around reasons for needing our help (enabling us to identify which other support services might be needed).

At the end of the registration conversation, we move onto Lara's food order for the week and Sam, the support worker, speaks: "Excuse me, would you mind...would it be possible if I could have some food too?"

She starts to cry. "I'm really struggling at the moment. I just don't have enough to get by." And of course, we register Sam too, and give her food for the week.

Sadly, finding support workers need help too is not an uncommon story. In recent months a significant number of our new guest registrations are people in work. We help Andrew, a medical courier driver, who also cares for his invalid father. Andrew's hours have been cut. He comes to the food bank on his motorbike in between drops. We help Vida, who cleans, and has a husband who is a warehouse packer. Aminata, who works in hospitality, and only finds out on Monday what her hours are (if she has any at all). Weekly hours are uncertain and insecure. This makes childcare problematic. Plus, if work hours suddenly increase and too many hours are worked, our guests can be hit with crippling benefit deductions.

It's been a month now since the Universal Credit cut and we're already seeing devastating effects. Higher weekly registrations plus more complex poverty issues linked to the cut: debt, health issues, family breakdown, housing problems etc. Not to mention specific problems caused by covid: missing work through self-isolation, children falling behind at school, and of course the grief from losing family members (it should be remembered that covid mortality rates are higher in more deprived neighbourhoods).

Recently we had a family with a newborn baby who can't afford to heat their home. "Eating vs heating" is an awful dilemma that we're seeing more regularly, as guests struggle with the rise in energy prices alongside the cut in universal credit. And, of course, furlough ended on 30 September 2021-another factor that is worsening financial hardship.

We try to help people with support services-we have a Citizens Advice advisor onsite and we also help guests to apply for emergency discretionary grants from Wandsworth Council. However, grant applications are not always successful. And even if they are, it is often too little too late. Children have already missed meals or slept in coats because their flat isn't warm enough.

We're also seeing the return of previous guests. People who used our food bank a while ago but had managed to get back on their feet. They were getting by, slowly getting life back on track after the disruption of covid, but now have been thrown back into stark poverty.

Some new guests tell us that this time last year they used to donate to the food bank, but now they can't get by without us. We now have several guests with mortgages-unheard of a few years ago. It is estimated that the universal credit cut will plunge at least 840,00 into poverty, including almost 300000 children. In just one month, what we're seeing at our food bank confirms our worst fears about the cut. ${ }^{1}$ Unless the government reverses its decision to reduce universal credit payments at a time when household costs have increased, we'll be seeing yet more people plunged into poverty. An emergency food parcel will only ever be a sticking plaster until such time as wages, job security, and social security payments ensure people can afford the bare essentials.

And we're just a small independent food bank serving a relatively small area of south-west London. What we're seeing is the tip of the iceberg. We are terrified about what we're going to see in the coming winter months here, and at food banks across the country. Some people talk about the crisis period being over. But we fear the real crisis is only just beginning.

Competing interests: none declared

Provenance and peer review: not commissioned, not peer reviewed

All names changed

The Earlsfield Foodbank is a member of the Independent Food Aid Network (IFAN) and supports people unable to afford food in Wandsworth, London. BM readers raised more than $\mathrm{f} 60000$ on behalf of IFAN during last year's BM] Annual Appeal. IFAN supports, connects and advocates on behalf of a range of food aid providers including over 500 independent food banks. BMJ readers' donations supported member organisations directly and contributed to IFAN's work to co-develop cash first referral leaflets to help reduce the need for emergency food aid.

Goodwin S. Food poverty set to worsen as September's Universal Credit cliff edge approaches. BMJ Opinion. August 2021

https://blogs.bmj.com/bmj/2021/08/26/food-poverty-set-to-worsen-asseptembers-universal-credit-cliff-edge-approaches/ 